https://ejournal.uniska-kediri.ac.id/index.php/PROFICIENCY

\title{
THE EFFECTIVENESS OF USING ORAL PAIR WORK TECHNIQUE IN TEACHING SPEAKING AT DEC (DYNAMIC ENGLISH COURSE) PARE KEDIRI
}

\author{
By: Izzatul Mufidah
}

\begin{abstract}
This study aims at knowing how effectiveness of oral pair work technique in teaching speaking at DEC. The research design which is used in this research was descriptive quantitative experimental with two groups of experimental class and control class. The subjects of this research were the holiday program of SMA A and SMA B. The instruments used were post-test. The data gotten were statistically computed by SPSS.The result reveals that experimental group outperformed the control group with significance value $0.2 \%$ or 0.002 at either $5 \%$ or $1 \%$ significancy level. So, it can be concluded that teaching speaking by using oral pair work technique is effective.
\end{abstract}

$\overline{\text { Key Words: effectiveness, oral pair work technique, teaching speaking }}$

\section{INTRODUCTION \\ Background of Study}

English is the international language. Many people aware to increase their English abilities, one of them is communication skill by English. speaking is part of skill that has purpose to make someone talk and use English for having communication to express the need to someone else. It's also related in teaching speaking, that the goal of teaching skill is students are able to speak English accurately and fluently.

Making students speak English accurately and fluently is not easy because speaking is complex skill, as the statement of Pollard, speaking is one of the most difficult aspects for students to master, (Pollard, 2008:33). Problem that found in teaching speaking is solved by many ways. Teacher, method, and technique are the solutions to improve the speaking ability that every one of the solution is completed each other.

Oral Communicative Language Teaching is a method in communicative approach, Richards and Rogers (1986) quoting La Forge (1983:91) in Abdulla (2006), declare that oral communicative language "is more than just a message being transmitted from a speaker to a listener; the speaker is at the same time both subject and object of his own message". In oral activity, applying oral communication give the students a big opportunity to apply their speaking in the class. Teacher may practice the oral activity in pair work, group work, or whole class discussion. According to (Achmad and Yusuf (155):2014) Pair-work is more efficient than group or whole class discussion as 
https://ejournal.uniska-kediri.ac.id/index.php/PROFICIENCY

every student gets the pportunity to speak, especially for introvert students who are irresolute to talk in front of the whole class or teachers.

According to Moon (2000:53) in European Scientific Journal January (2014) stated "to organize students in ways that will maximize opportunities for learning is by pair work" from the statement above we could interpret that pair work is a technique that maximize the students to share and discuss.Pair work is an effective strategy that could lead to success in language learning because it helps to increase students' interest in term of the oral tasks.

The English teacher must master the technique in teaching English to succeed student's speaking. So students can enjoy English speaking, as one of the easy and comfortable lessons to be learned. By looking at the reason above, The researcher take data from the students in DEC because the students of course has no limitation material as in formal students that have to follow government's curriculum.

\section{Research problem}

Based on background of study, some focuses can be identified as follows:

1. How is the students' speaking ability in experimental class at Dynamic English Course (DEC) Pare?

2. How is the students' speaking ability in control class at Dynamic English Course (DEC) Pare?

3. How is the difference between the post test of experimental and control class at Dynamic English Course (DEC) Pare?
4. How is the effectiveness of using oral pair in teaching speaking at Dynamic English Course (DEC) Pare?

\section{Objective of the study.}

Based on background of study, objectives of study are formulated as follows:

1. To analyze the students' speaking ability in experimental class at Dynamic English Course (DEC) Pare

2. To analyze the students' speaking ability in control class at Dynamic English Course (DEC) Pare

3. To analyze the differences between the post test of experimental and control class at Dynamic English Course (DEC) Pare

4. To analyze the effectiveness of using oral pair work in teaching speaking at Dynamic English Course (DEC) Pare

\section{Research hypothesis.}

This thesis has two hypotheses. They are null hypotheses (Ho) and alternative hypothesis (Ha). The null hypothesis (Ho) states that teaching speaking by using oral pair work at DEC Pare is not effective. The alternative hypothesis (Ha) for this research can be formulated: teaching speaking by using oral pair work at DEC is effective. From these hypotheses, the researcher uses the alternative hypotheses $(\mathrm{Ha})$ because taking a learning theory of Moon (2000:53) in Said Zohairy (2014:51), to organize students in ways that will maximize opportunities for learning is by pair work oral. 
https://ejournal.uniska-kediri.ac.id/index.php/PROFICIENCY

\section{Limitation of the study}

This research is focus in find out the effectiveness of using oral pair work in teaching speaking at DEC (Dynamic English Course). The scope of material in this thesis is speaking. The limitation of this speaking is describing in 10 meetings. In describing session, the students have to be able to describe the picture, place, environment and the object around the students orally by concerning the grammar, vocabulary, pronunciation, fluency, and comprehension.

Besides, the approach in this research is communicative approach. The method in communicative approach that is used are Communicative Language Teaching (CLT) and Cooperative learning. For the technique of this research is limited by pair work technique. The scope of place this research in DEC (Dynamic English Course). The limitation in this research was HP SMA A as control, and HP SMA B was as experimental class.

\section{METHODOLOGY.}

\section{The Subject of the Research}

The subject of the research is the students at DEC which is located at Flamboyan 9 Street Pare Kediri. In determining the subject, the researcher used quasi experimental sampling. So the class were taken as the subject of study without pretest, because all the class had the same ability. The researcher chose the holiday class of SMA $B$ as experimental class consist of 21 students; they are 12 female students and 9 male students and SMA A as control class consist of 17 students; they are 12 female students and 5 male students.

\section{Topic being taught.}

The topic taught in this study is speaking around describing session, the students have to be able to describe the picture, place, environment and the object around the students orally by concerning the grammar, vocabulary, pronunciation, fluency, and comprehension.

\section{Teaching process.}

Teaching speaking in this research was giving the materials to the students' how to produce speaking skill and how to communication in order to master the component of speaking, includes; grammar, pronunciation, vocabulary, fluency, and comprehension. To get the goal of speaking, the researcher used the pair work technique in grouping student to practice the process of teaching speaking in the class, that is able to motivate and engage the students to use or practice the language properly. The pairs are divided two by two after giving the material. When all the students are participating fully with the pair by discussing and sharing the speaking task, it is mentioned as Rehearsal, the teacher give useful feedback by having some question and answer until the students have tremendous satisfaction from the class activities, and thus speaking becomes intrinsically enjoyable tasks for themselves, it is called as Feedback. And the last process is giving the students' time to engage speaking independently, it is named Engagement. Those ways will 
https://ejournal.uniska-kediri.ac.id/index.php/PROFICIENCY

maximize opportunities for oral describing.

So here are the steps from the process of speaking with oral pair work technique: (1) Brainstorming the material and model, (2) Dividing students into pairs, (3) Asking the students to discuss and share the topic to the pair (Rehearsal), (4) Asking the students to ask, answer and describe to the pair or other pair, while teacher give the response (Feedback), (5) Practice the demonstration of speaking (Engagement).

\section{Data Collection}

Technique of Data Collection was the process to collect the data of the test by the instrument. The data was collected by having a test. Before having a test, the researcher as the examiner prepared the lottery that every lottery had a topic inside, they were; the picture, place, environment and the object around the students. And examiner prepared the list of test score the students' in experimental class and control class.

The test was held with grammar test in one time, while doing grammar test the students were called forward one by one. Then each student took a lottery that had been provided by the examiner. After getting a topic the lottery, the student got a minute to plan how to describe the topic. Then student described the topic orally for 3 minutes. The examiner took the score by speaking rubric adopted from D.P. Harris. The points that should be scored are: (1) the fluency of speaking (2) the accuracy of grammar pronunciation (4) the comprehension (5) the vocabulary.

\section{RESULT AND DISCUSSION}

After got the data, the researcher calculated it statistically used SPSS software version 22. These results are explained below:

\section{Table 1 The Statistic Data of Experimental}

\begin{tabular}{|c|c|c|}
\hline \multirow{2}{*}{$\mathrm{B}$} & \multicolumn{2}{|l|}{ Statistics } \\
\hline & & \\
\hline \multirow[t]{2}{*}{$\mathrm{N}$} & Valid & 21 \\
\hline & Missing & 0 \\
\hline \multicolumn{2}{|l|}{ Mean } & 82,86 \\
\hline \multicolumn{2}{|l|}{ Median } & 84,00 \\
\hline \multicolumn{2}{|l|}{ Mode } & 96 \\
\hline \multicolumn{2}{|c|}{ Std. Deviation } & 12,721 \\
\hline \multicolumn{2}{|l|}{ Variance } & 161,829 \\
\hline \multicolumn{2}{|l|}{ Range } & 44 \\
\hline \multicolumn{2}{|l|}{ Minimum } & 52 \\
\hline \multicolumn{2}{|l|}{ Maximum } & 96 \\
\hline \multicolumn{2}{|l|}{ Sum } & 1740 \\
\hline \multirow[t]{3}{*}{ Percentiles } & 25 & 74,00 \\
\hline & 50 & 84,00 \\
\hline & 75 & 96,00 \\
\hline
\end{tabular}

From the result of posttest, the researcher got the data from SPSS 22 versions which could be seen, the highest score was 96 and the lowest score was 52, while the range was 44. Besides that, the mean of variable was 82.86 , the median of variable was 84.00 and the mode was 96. The average of posttest of students' score in experimental class was very good because the mean 82.86 was among the range 81-100 which was categorized as very good. 
https://ejournal.uniska-kediri.ac.id/index.php/PROFICIENCY

Table 2 The Statistic Data of Control Class

\begin{tabular}{|c|c|c|}
\hline & Statistics & \\
\hline \multirow[t]{2}{*}{$\mathrm{N}$} & Valid & 17 \\
\hline & Missing & 0 \\
\hline Mean & & 68,00 \\
\hline Median & & 68,00 \\
\hline Mode & & $56^{\mathrm{a}}$ \\
\hline Std. Deviation & & 14,491 \\
\hline Variance & & 210,000 \\
\hline Range & & 56 \\
\hline Minimum & & 40 \\
\hline Maximum & & 96 \\
\hline Sum & & 1156 \\
\hline \multirow[t]{3}{*}{ Percentiles } & 25 & 56,00 \\
\hline & 50 & 68,00 \\
\hline & 75 & 80,00 \\
\hline
\end{tabular}

a. Multiple modes exist. The smallest value is shown
From the result of post test, the researcher got the data from SPSS 22 versions which could be seen the highest score was 96 and the lowest score was 40, while the range was 56. Besides that, the mean of variable was 68.00 the median of variable was 68.00 and the mode was 56 . The researcher then concluded it to the system of score category and found that the average of posttest students 'score in control class was good because 68.00 was among the range 61-80 which was categorized as good.

\section{The Differences Between the Post Test of Experimental and Control Class at Dynamic English Course (DEC) Pare}

Table 3 Independent Sample Test

\begin{tabular}{|c|c|c|c|c|c|c|c|c|c|c|}
\hline \multicolumn{11}{|c|}{ Independent Samples Test } \\
\hline & & \multicolumn{2}{|c|}{$\begin{array}{l}\text { Levene's Test } \\
\text { for Equality of } \\
\text { Variances }\end{array}$} & \multicolumn{7}{|c|}{ t-test for Equality of Means } \\
\hline & & \multirow[t]{2}{*}{$\mathrm{F}$} & \multirow[t]{2}{*}{ Sig. } & \multirow[t]{2}{*}{$\mathrm{t}$} & \multirow[t]{2}{*}{ df } & \multirow[t]{2}{*}{$\begin{array}{l}\text { Sig. (2- } \\
\text { tailed) }\end{array}$} & \multirow{2}{*}{$\begin{array}{c}\text { Mean } \\
\text { Differen } \\
\text { ce }\end{array}$} & \multirow{2}{*}{$\begin{array}{c}\text { Std. } \\
\text { Error } \\
\text { Differen } \\
\text { ce }\end{array}$} & \multicolumn{2}{|c|}{$\begin{array}{l}\text { 95\% Confidence } \\
\text { Interval of the } \\
\text { Difference }\end{array}$} \\
\hline & & & & & & & & & Lower & Upper \\
\hline \multirow{2}{*}{$\begin{array}{l}\text { Sco } \\
\text { re }\end{array}$} & $\begin{array}{l}\text { Equal variances } \\
\text { assumed }\end{array}$ & \multirow[t]{2}{*}{,343 } & \multirow[t]{2}{*}{, 561} & 3,364 & 36 &, 002 & 14,857 & 4,416 & 5,900 & 23,814 \\
\hline & $\begin{array}{l}\text { Equal variances } \\
\text { not assumed }\end{array}$ & & & & 32,173 &, 002 & 14,857 & 4,479 & 5,736 & 23,978 \\
\hline
\end{tabular}

From the table above, there is significant difference between two groups if sig. (2-tailed) value is the same as or is lower than $5 \%$ or 0.05 . From table 4.3.1, it can be seen that the experimental group outperformed the control group in speaking achievement with significant ,002. And it was known that $t$ value of experimental class was 3,364; degree of freedom was 36 and mean difference of the variable was 14,857 and the last was about $99 \%$ confidence interval of the difference from the lower value was 5,900 and the upper value was 23.814. Thus, the significance different between the mean values of both groups is found.

The Effectiveness of Using Oral Pair in Teaching Speaking at Dynamic

Oral pair work, which is used as teaching technique in this 
https://ejournal.uniska-kediri.ac.id/index.php/PROFICIENCY

research, is 'effective' because the research findings show some indicators, those are; 1) the mean score of experimental group $(\mathrm{M}=$ 82.86 ) is higher than control group $(\mathrm{M}=68.00) ; 2)$ the result reveals that experimental group outperformed the control group with significance value $0.2 \%$ or 0.002

\section{CONCLUSIONS AND RECOMMENDATION}

From explanation in result and discussion part before, it can be seen that teaching speaking by using pair work technique is effective. It is proven by the mean test of experimental class 82.86 is higher than the mean test of control class 68.00. Then, there is significant difference between the test of experimental class and control class.
From SPSS result shows that the result is significant at two tails. Consulting to t-table, the result is higher than t-table at either $5 \%$ or $1 \%$ significance level. In the 5\% level, the value is, 002 . So, the value is significant at $1 \% .5 \%$ level here is $99 \%$ from $100 \%$ are success by using pair work strategy and $1 \%$ from $100 \%$ not influence by using this strategy. It means that teaching speaking by using oral pair work technique at Dynamic English Course (DEC) Pare Kediri is effective. So, the alternative hypothesis is accepted. So, the teacher can apply this technique for the students to get the successful speaking. Student can enjoy their communication with the friends by the target language.

\section{REFERENCES}

Abdulla Moaza Aziz Ahmad. 2006. Enhancing Oral Communication Skills Through Pairwork Strategies. Dubai : Dubai Women's College.

Achmad, D., \& Yusuf, Y.Q.Y. (2014). Observing pair-work task in an English Speaking Class. International Journal of Instruction, 7(1), 151-164.

Littlewood, William T. (1981) Communicative language teaching. Cambridge: Cambridge University Press.

Moon, J. (2000). Children learning English. Oxford: Macmillan Heineman Publishers
Pollard, Andrew. (2008). Reflective Teaching. London: Continuum

Westbrook, F. (2011). Lessons from the other side of the teacher's desk: Discovering insights to help language learners. English Teaching Forum, 49(1): 2-7

Zohairi Said. 2014. Effective Pairwork Strategies to Enhance Aaudi PreItermediate College Students' Language Production in Speaking Activities. Saudi Arabia : MA, University of Sunderland 